Ethos (Jurnal Penelitian dan Pengabdian Masyarakat): 75-84

\title{
Sillau'na Tongkonan Sebagai Sebuah Realitas TondoK
}

\author{
${ }^{1}$ Imam Indratno, ${ }^{2}$ Sudaryono, ${ }^{3}$ Bakti Setiawan, ${ }^{4}$ Kawik Sugiana \\ ${ }^{1}$ Mahasiswa S3 Program Studi Perencanaan Wilayah dan Kota, Jurusan Teknik Arsitekturdan \\ Perencanaan, Fakultas Teknik, Universitas Gadjah Mada \\ ${ }^{2,3,4}$ Program Studi Perencanaan Wilayah dan Kota, Jurusan Teknik Arsitektur dan Perencanaan, \\ Fakultas Teknik, Universitas Gadjah Mada \\ Email: ${ }^{1}$ akudandirikul@gmail.com
}

\begin{abstract}
Abstrak. Tongkonan merupakan simbol kebudayaan pada masyarakat Toraja yang dilandasi filosofi dasar Tallu Lolona. Tallu Lolona adalah sebuah spirit yang membentuk relasi hubungan antara manusia dengan Tuhan, manusia dengan manusia dan manusia dengan tumbuhan serta binatang. Penelitian dilakukan dengan paradigma dan pendekatan fenomenologi. Dengan pendekatan fenomenologi, peneliti berusaha untuk mendesk ripsikan pengetahuan lokal yang ada di Lembang Sillanan. Hasil penelitian menunjukkan bahwa tongkonan sebagai elemen utama tondok merupakan simbol tingkatan yang ada dalam ruang. Konsep hirarki ruang (silau'na) tongkonan muncul dilandasi oleh realitas bahwa tongkonan tidak bisa hanya dilihat an sich sebagai bentuk fisik tetapi juga merupakan manisfestasi kebudayaan bermasyarakat di Sillanan.
\end{abstract}

Kata Kunci: Silau'na Tongkonan dan Tondok

\section{Pendahuluan}

Kompleks Kampung Adat Tua Sillanan berada di bawah kaki bukit Suriak dengan ketinggian rata-rata $1200 \mathrm{dpl}$. Tata letak permukiman tongkonan Kampung Adat Tua Sillanan yang mengumpul dalam satu lokasi menunjukkan fenomena yang berbeda dengan tata permukiman komunitas adat di Toraja khususnya komunitas adat Kapuangan sebagai induk komunitasnya. Tongkonan layuk pada komunitas adat Kapuangan tidak menyatu dengan fungsi yang pendukungnya sebagai bentuk hirarki atau struktur kepemerintahan yang bersifat aristokrasi. Tongkonan layuk pada komunitas adat Talulembangna juga berada pada posisi paling tinggi di antara seluruh struktur tongkonan komunitas. Dengan nama yang berbeda, tongkonan tertinggi pada komunitas adat Sillanan dikenal dengan nama tongkonan karua. Tongkonan Karua Bara' Pai'pinan sebagai tongkonan pemimpin menempati lokasi yang tidak tertinggi dalam kompleks Kampung Adat Tua Sillanan. Fenomena tersebut menunjukkan ada bentuk kebudayaan yang berbeda antara komunitas adat Sillanan dengan induknya (komunitas adat Tallulembangna).

Tipe atau Tata Ruang Bangunan setiap tongkonan yang ada di perkampungan adat Sillanan terutama yang berfungsi adat dan tergolong Tongkonan Karua jumlah ruangnya terdiri atas empat petak atau tipe banua patang lanta' yang terdiri atas: paliuang, sali, sumbung dan sumbung lendu' sau'. Sedangkan tongkonan lainnya ada 
yang tiga petak (tallung lanta') dan ada yang dua petak (duang lanta') terutama bagi tongkonan yang berfungsi batu a'riri. Selain itu di beberapa rumah pada bagian depan ada ruang yang hanya berdinding setengah yang disebut tangdo' sebagai ruang peralihan yang merupakan ciri khas tongkonan di Sillanan. Bahkan di Tongkonan Sissarean di Karampa Selatan, ruang tangdo' sekaligus berfungsi sebagai dapur. Dan inilah yang spesifik sebab justru dapur berada di tangdo' bukan di sali seperti tongkonan lain pada umumnya. Selain dari empat ruang utama dan tangdo' pada sisi kanan rumah memanjang dari utara ke selatan sepanjang badan rumah, di beberapa rumah ada lantai terbuka setinggi 40-60 cm dari muka tanah yang disebut Paranta' biasanya digunakan untuk duduk-duduk santai atau menyimpan barang/peralatan lainnya.

Seiring berjalannya waktu, tampak perubahan bentuk yang sangat besar terutama pada lengkungan atap. Bentuk dahulu tidak terlalu melengkung dan pada bagian longa (depan rumah) ada atap bersusun untuk menutupi tangdo', sementara bentuk sekarang sudah tidak ada lagi, akibatnya bentuk asli yang spesifik itu tidak dibuat lagi dan bentuk seperti ini terancam punah. Perubahan bentuk ini diperkirakan terjadi ketika tongkonan yang tua sudah lapuk, kemudian direnovasi. Selain itu, berdasarkan informasi masyarakat sekitar bahwa tukang yang mengerjakan renovasi ini berasal dari utara Toraja (Rantepao dan sekitarnya). Pendapat ini didukung oleh Stanislaus Sandarupa (2001), yang mengatakan 'Perubahan bentuk saat ini juga dipengaruhi oleh adanya 'traveling' antar kelompok dari utara ke selatan dan sebaliknya' (Mithen Lullulangi, Arsitektur Tradisional Toraja, 2008). Selain Tongkonan Bara' Pai'pinan, Tongkonan Doa' (Pong Arruan) dan Tongkonan Tora Tondok (Sangtane'te) yang mengalami perubahan, hampir seluruh tongkonan yang ada dalam kawasan perkampungan adat ini mengalami perubahan, tetapi hanya sedikit yang masih mempertahankan bentuk dahulu.

\section{Tujuan Penelitian}

Tujuan penelitian adalah menemukan bentuk realitas ruang yang ada di Lembang Sillanan, Kecamatan Gandangbatu Sillanan, Kabupaten Tana Toraja. Penelitian ini menggunakan pendekatan fenomenologi yang berusaha mengungkapkan realitas tongkonan di Tanga Tondok.

\section{Tongkonan Sebagai Pusat Kosmologi}

Kosmologi merupakan salah satu bagian dari pembahasan metafisika di samping ontologi. Dinamika kebudayaan Toraja beserta proses transformasinya tidak akan lepas dari kajian kosmologi. Beberapa peneliti Toraja baik dari dalam maupun luar negeri seperti (Palm, 1979), (Waterson, 2009), (Bigalke, 1981; 2005), (Sandarupa, 1996), (Betteng, 1997), (Lullulangi dan Sampebua', 2007) telah membahas kosmologi. Kajian kosmologi Toraja erat kaitannya dengan kepercayaan atau agama asli masyarakat Toraja. 
Masyarakat Tana Toraja memiliki kepercayaan / aturan keagamaan yang dikenal dengan nama aluk. Kepercayaan ini diperkirakan sudah dianut oleh masyarakat Toraja sejak abad ke-IX Masehi. aluk merupakan aturan religi yang menjadi sumber budaya dan pandangan hidup leluhur Toraja yang mengandung nilai-nilai religius yang mengarahkan pola-pola tingkah laku hidup maupun ritual orang Toraja untuk mengabdi kepada Puang Matua (Pencipta). Kepercayaan aluk mengenal dua sistem berjenjang dalam kehidupan manusia di dunia, yaitu :

a. Aluk tuka', yang berarti keberuntungan, kebahagiaan, atau keselamatan

b. Aluk solo', yang berarti kesusahan, kematian, atau kehancuran.

Menurut Hetty Nooy-Palm, 1979 menjelaskan bahwa prinsip klasifikasi kosmologi Toraja berdasarkan pada perilaku ritual terbagi atas klasifikasi atas - bawah dan timur - barat. Dua dasar pasangan tersebut saling berhubungan dan mengalami polaritas membentuk utara - selatan. Utara dihubungan dengan timur dan atas sedangkan selatan dihubungakan dengan barat dan bawah. Dalam perspektif klasifikasi atas - bawah, menurut ajaran Aluk Todolo, beranjak dari pandangan bahwa di luar diri manusia terdapat tiga unsur kekuatan yang wajib dipercayai akan kebenaran, kebesaran, dan kekuasaanya. Berdasar pada pandangan tersebut, pembagian alam raya ini (kosmos) yang terbagi menjadi tiga bagian, yaitu:

1) Puang Matua (Tuhan), unsur kekuatan tertinggi sebagai pencipta bumi, langit, dan segala isinya menempati Dunia Atas, langi' (langit) atau dalam bahasa puitis Toraja: suangan;

2) Deata-deata (penguasa dan pemelihara bumi) menempati Dunia Tengah, lino atau padang, yang ditempati manusia, serta;

3) Tomembali Puang (arwah para leluhur yang telah menjelma menjadi dewa) menempati Dunia Bawah, tempat bersemayamnya deata to kengkok.

'Dunia Atas' berada pada tingkat tertinggi, ulunna langi' (kepala langit) tempat bersemayam Puang Matua (Tuhan yang maha Tinggi), yang menjaga keseimbangan siang dan malam di dunia dan diasosiasikan dengan 'matahari', yang mana merupakan sesuatu yang tidak tergantung pada apapun, disebut allo (siang hari/terang) dan diidentifikasikan sebagai laki-laki, berada di atas, terang dan baik. 'Dunia Tengah' berada di permukaan bumi tempat manusia menjalani kehidupan (padang), dan wajib melaksanakan upacara-upacara persembahan dan pemujaan dalam tiap fase kehidupannya. Selain itu, dunia ini merupakan tempat pertemuan antara Dunia Atas dan Dunia Bawah karena itu dikonotasikan sebagai kerukunan, kegotong-royongan, dan yang terpenting mewakili pengertian harmonisasi. 'Dunia Bawah' berada di bawah air, diidentifikasi sebagai bawahan dan buruk (neraka). Bagian ini ditopang diatas kepala dewa Pong Tulak Padang yang mendukung dan memberikan spirit (semangat) pada Tongkonan dan kehidupan manusia di bumi.

Sedangkan untuk klasifikasi timur-barat lebih banyak dihubungkan dengan tongkonan dan tahapan kehidupan manusia, kelahiran dianggap sama dengan arah timur (matallo dari allo/matahari). Tongkonan sendiri berasal dari bahasa Toraja "tongkon" 
yang berarti duduk. Masyarakat Toraja sendiri mengartikan tongkonan sebagai "rumah yang diberi fungsi, tugas dan kewajiban", atau suatu sistem kelembagaan dalam keluarga. Pada satu pihak ada tongkonan tanda indo' yaitu tongkonan yang menyatukan semua rumpun keluarga pada ibu ego dan itu dikenal sebagai sang rapu tanda indo', 'satu rumpun keluarga dari sisi ibu'. Dengan demikian tongkonan berarti sistem kekerabatan yang didasarkan pada prinsip sang rara sang buku (sedarah dan setulang).

Orientasi tongkonan selalu menghadap ke utara (ulunna lino) sebagai simbol penghormatan pada Puang Matua. Bagian selatan (pollo'na lino) menghadap ke arah pollo' banua atau puya, sebagai representasi hubungan dengan para leluhur dan kehidupan setelah kematian. Arah barat (matampu') dan timur (matallo) menggambarkan bagian kiri dan kanan tubuh, selain itu bagian timur juga melambangkan hubungan dengan para dewa, sedangkan di bagian barat melambangkan hubungan dengan para leluhur yang dihormati.

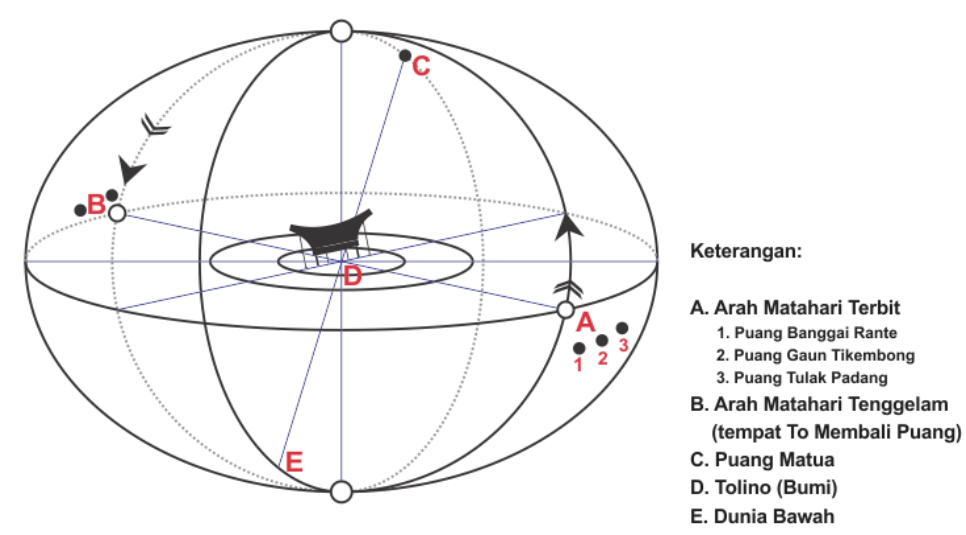

Sumber : Lullulangi dan Sampebua, 2007

\section{Gambar 1: Superposisi dari Kosmologi Tradisional Toraja}

\section{Telaah Ontologis: Silau'na Tongkonan}

Konsep hirarki ruang (silau'na) tongkonan muncul dilandasi oleh realitas bahwa tongkonan tidak bisa hanya dilihat an sich sebagai bentuk fisik tetapi juga merupakan manisfestasi kebudayaan bermasyarakat di Sillanan. Hal ini sejalan dengan pernyataan Theodoros Kobong yang mendefinisikan tongkonan dari aspek fisik dan aspek kekerabatan keluarga besar. Pernyataan Stanis Sandarupa dalam meta narasi memberikan penguatan terhadap adanya gagasan hirarki ruang tongkonan. Tongkonan sebagai simbol kebudayaan memberikan arah adanya tingkatan seperti tingkatan yang ada dalam kebudayaan. Konsepsi Tallu Lolona memberikan arahan bahwa tingkatan dalam ruang tongkonan didorong oleh adanya sebuah spirit yang berbasis kepada pandangan teologis masyarakat Toraja. 


\subsection{Tingkat 1 : Manifestasi Fisik}

Tingkatan manifestasi fisik merupakan bentuk produk budaya yang berkembang di masyarakat Sillanan. Bentuk manifestasi fisik yang dapat ditunjukkan adalah adalah ruang spasial permukiman masyarakat maupun tanda dalam bentuk bangunan. Bangunan yang dapat dijadikan tanda adalah tongkonan dan gereja yang merupakan simbol kehidupan masyarakat Sillanan.

Eksistensi Tangga Tondok Sillanan sebagai perkampungan awal komunias Sillanan merupakan sebuah bukti adanya manisfestasi produk budaya Komunitas Sillanan. Kumpulan tongkanan baik tongkonan yang berfungsi karua, fungsi pembantu dan fungsi khusus yang berjumlah 3 tongkonan adalah manifestasi fisik dari kebuadayaan yang telah dijalankan oleh masyarakat Sillanan secara turun temurun ratusan tahun. Ruang spasial ini tidak hanya berupa tongkonan tetapi berupa sebuah tondok, yaitu perkampungan yang terdiri dari beberapa tongkonan berikut dengan berbagai pendukungnya seperti sawah, padang atau tegalan, bubun, rante berikut karopi dan simbuang, liang dan patane, panglambaran dan kebun bambu.

Perkembangan penduduk yang semakin banyak berdampak pada tidak mencukupinya kebutuhan tinggal tinggal di Tangga Tondok. Dengan pertimbangan dengan dengan kebun, maka sebagian masyarakat memilih bertempat tinggal di perbukitan. Pertimbangan lain adalah karena sistem pengetahuan dan budaya dalam masyarakat aluk yang menempatkan sawah menjadi asset yang paling berharga sehingga mereka memilih tinggal di Buntu agar dataran yang lebih landai dapat dipergunakan untuk menanam padi. Pola ini adalah bentuk kedua dari corak bermukim yang ada di Sillanan. Tampak bahwa suatu penetapan pola permukiman di adat tua menggunakan aturan kosmologi lokal yang menjadikan gunung sebagai patokan atau yang disebut juga environmisme aluk. Sehingga dapat diketehui bahwa yang mempangruhi pola bermukim masyarkat sillanan ada dua aspek yaitu konteks sosiohistoris dan kondisi alam yang ada di Tangga Tondok Sillanan.

Selain itu sebagai ciri Tangga Tondok yaitu tondok sebagai permukiman sekaligus pertahanan pada saat terjadi perang suku. Namun seiring dengan berjalannya waktu dan peradaban semakin berkembang, terjadi beberapa pergeseran yang berdampak pada ruang hunian di permukiman tradisional. Selain itu fungsi tongkonan karua masih menyisakan permasalahan yang cukup sensitif di kalangan warga. Silang pendapat antar kelompok warga tentang tongkonan yang mempunyai fungsi utama antara Tongkonan Indo Piso dan Tongkonan Tobarana belum mampu dipecahkan oleh warga. Permasalahan yang kedua terkait dengan asset yang dimiliki oleh masing-masing tongkonan. Tidak terdapat bukti tertulis tentang asset dari masing-masing tongkonan sehingga sangat menyulitkan untuk menelusuri pola kepemilikan asset tongkonan.

Pola ketiga sebagai manifestasi fisik dalam ruang ditandai dengan perkembangan permukiman yang linier mengikuti pola jaringan jalan. Tuntutan akan ekonomi telah merasionalisasi tindakan masyarakat untuk mengembangkan budaya kopi, coklat dan cengkih yang memberikan nilai tambah lebih besar dibandingkan 
tanaman padi. Dekade 60an telah menjadi tonggak perkembangkan pola bermukim masyarakat Sillanan. Dengan kata lain seiring dengan berjalannya waktu dan dinamika pembangunan ekonomi masyarakat berdampak pada alih fungsi lahan dan tongkonan yang sudah tidak ditempati. Sehingga sekarang ini ada tiga tipe permukiman di Sillanan diantaranya adalah permukiman tradisional toraja (tongkonan) yang memiliki fungsi, permukiman tradisional tongkonan yang tidak memiliki fungsi, dan rumah bugis serta rumah modern.

\subsection{Tingkat 2 : Dimensi Aktivitas}

Dimensi kedua dalam hirarki ruang tongkonan adalah dimensi aktivitas komunitas. Dimensi ini merupakan bentuk berbagai aktivitas sosial, ekonomi, budaya, dan politik dari masyarakat yang telah menghiasi dinamika kehidupan masyarakat. Proses aktivitas inilah yang menjadi sebab termanifestasinya produk fisik berupa tongkonan atau permukiman masyarakat Sillanan. Ritual dalam ajaran Aluk Todolo telah melahirkan budaya masyarakat dalam bentuk upacara rambu solo' dan rambu tuka'. Upacara ini menempatkan tongkonan sebagai pusat kegiatan upacara. Aktivitas sosial ekonomi dalam memanfaatkan adat sumberdaya tongkonan sebagai bentuk aktivitas yang menunjukkan eksistensi ruang tongkonan dalam kebudayaan masyarakat Sillanan.

Pertemuan dua identitas (tongkonan dan gereja) berdampak pada dinamika kehidupan masyarakat sillanan. Pergeseran pusat budaya ternyata memberikan dampak pada berbagai bentuk relasi yang ada dalam masyarakat. Beberapa perubahan yang cukup signifikan terjadi pada ritual upacara rambu tuka'. Berbagai hal yang bertentangan dengan ajaran Kristen dihilangkan. Namun muncul terminologi baru dalam proses upacara seperti istilah Puang Yesus untuk mengganti Puang Matua yang dikenal sebagai sosok tertinggi dalam ajaran Aluk Todolo.

Relasi yang mengalami perubahan terjadi pada motif pemanfaatan sumberdaya tongkonan. Ketika awal peradaban, komunitas Sillanan lebih menekankan pada implementasi nilai keseimbangan lingkungan ketika berhubungan dengan tumbuhan dan hewan. Hal tersebut sejalan dengan nilai yang terkandung dalam konsepsi Tallu Lolona. Namun seiring dengan perkembangan waktu, motif tersebut telah bergeser menjadi relasi yang lebih menekankan pada kapitalisasi sumberdaya. Sehingga tidak mengherankan terdapat konflik yang cukup tajam, bahkan terjadi pembunuhan, dalam proses pemanfaatan sumberdaya tongkonan Hal tersebut tentu telah mencederai makna kekerabatan yang ada dalam sebuah tongkonan, dimana tongkonan dapat berfungsi sebagai tempat untuk memecahkan permasalahan keluarga.

Peran pelaku yang berkepentingan dalam pelestarian budaya Sillanan pun telah mengalami pergeseran. Peran toparengge sebagai pemimpin sebuah tongkonan sekaligus pemimpin agama sudah sangat berkurang dalam dinamika kehidupan sosial budaya masyarakat. Hal in berdampak pada pergeseran peran sosial politik yang ada di dalam masyarakat. Selain itu dalam pemilihan londong tongkonan yang merupakan 
pemimpin sekaligus merupakan pemimpin agama dalam kepercayaan aluk yang seharusnya ditunjuk berdasarkan kesepakatan keluarga besar, namun sekarang ini sulit dilakukan karena peran ketua adat sudah sangat kecil. Lembaga adat juga tidak dibentuk sebagaimana mestinya, tetapi lembaga adat dibentuk oleh kepala lembang. Walaupun proses pengambilan keputusan masih dilakukan dengan cara musyawarah seperti yang dilakukan pada saat pemerintahan tradisional namun proporsi komunitas adat yang ikutserta sekarang ini jauh lebih sedikit dibandingkan pada saat dahulu. Hal tersebut berakibat pada peran yang semakin kecil dari lembaga adat pada satu sisi, telah mentransformasi lembaga gereja menjadi lembaga yang mempunyai peran sangat besar dalam dinamika kehidupan masyarakat Sillanan.

Semua itu menunjukan bahwa struktur dari perangkat unsur yang saling berkaitan sudah mulai mengalami degrasasi fungsi sehingga membutuhkan rekonstruksi atau revitalisasi fungsi tongkonan dalam konteks kekinian. Rohaniawan pun belum tampak mengambil peran cukup aktif dalam dinamika politik lokal yag ada di Sillanan. Percaturan politik lokal dari beberapa elit di komunitas Sillanan berdampak pada kurang perhatiannya terhadap komunitas Alukta yang menjadi bagian minoritas di Sillanan. Karena di Sillanan ini terdapat demokratisasi lokal yang berbeda denan pola pemerintahan di Toraja secara umum.

\subsection{Tingkat 3 : Dimensi Karakter Komunitas}

Tingkatan ketiga dari hirarki ruang tongkonan adalah dimensi karakter komunitas. Karakter adalah segala sesuatu yang menjadi ciri khas yang menjadi watak yang bersifat batin dan mempengaruhi segala pikiran, perilaku, budi pekerti dan tabiat komunitas Sillanan. Bila melihat fenomena yang terjadi di Sillanan tampak bahwa karakter komunitas dibentuk oleh dua aspek yaitu lingkungan dan pengetahuan komunitas.

Aspek lingkungan yang mempengaruhi komunitas Sillanan adalah alam pegunungan dengan ketinggian 1200 dpl. Barisan Buntu Suriak, Buntu Tomenpandung, dan Buntu Tumonga memberikan karakter lingkungan yang khas bagi komunitas Sillanan. Karakter lingkungan yang khas telah membangun pengetahuan kosmologi menjadi dasar bagi tatanan pola bermukim di Sillanan. Namun kosmologi yang ada di Sillanan berbeda dengan kosmologi yang berada di Toraja Pada umumnya. Buntu Suriak dan Buntu Tumonga sebagai arah orientasi pembangunan tongkonan di Komunitas Sillanan. Aliran Sungai Sallu Langsa yang berhulu di Buntu Tumonga telah memberikan sumber kehidupan Komunitas Sillanan. Keberadaan Buntu Suriak juga telah memberikan tanda adanya ruang atau tempat sakral di Sillanan. Puncak Buntu selain diyakini sebagai tempat bersemayamnya para dewa tetapi juga sebagai tempat pertama turunnya Tomanurun Tintiri Buntu. Dengan kata kepercayaan Aluk dan penghormatan terhadap alam memberikan karakter pada pola bermukim di Sillanan. 
Watak lain yang menjadi ciri Komunitas Adat Sillanan adalah keinginan untuk menciptakan perdamaian. Watak tersebut dilatarbelakangi oleh pandangan dan perasaan komunitas Sillanan sebagai masyarakat yang "Tomakaka" atau merdeka. Tempat sakral yang menjadi tanda adanya perjanjian perdamaian antara komunitas Sillanan dengan pihak luar adalah menhir atau prasasti yang merada di empat sudut Tongkonan Doa'. Adanya bukti empat menhir, artinya telah terjadi empat kali perjanjian untuk tidak saling menyerang antara masyarakat Sillanan dengan pihak luar yaitu : dengan masyarakat Kapuangan, masyarakat Mandar, Bugis, dan Goa. Bila melihat perjalanan dan dinamika kehidupan keagamaan masyarakat Sillanan, maka dapat dicermati bahwa hakekatnya masyarakat Sillanan adalah masyarakat religius. Selama ratusan tahun masyarakat menjadi pemeluk agama lokal Aluk Todolo. Artinya, tatanan Aluk merupakan sumber kesadaran masyarakat yang menjadi landasan perilaku masyarakat Sillanan. Seiring dengan perkembangan terutama pada dekade 90an, masyarakat Sillanan banyak yang berpindah agama menjadi Kristen terutama Kristen Protestan. Namun bila diamati lebih dalam secara psikologis, alam bawah sadar masyarakat masih mencerminkan keyakinan kepada agama leluhur masyarakat Sillanan. Hal ini kemungkinan karena saat ini adalah masa transisi dari keyakinan Aluk Todolo menjadi masyarakat Kristiani.

\subsection{Tingkat 4 : Dimensi Spirit}

Tingkatan keempat dari hirarki ruang tongkonan adalah dimensi teologis komunitas. Dimensi ini merupakan hakekat dari realitas ruang tongkonan. Dimensi ini telah memberikan spirit bagi termanifestasinya berbagai watak atau karakter masyarakat Sillanan. Berbagai nilai yang terkandung dalam ajaran Alukta telah memberikan jiwa bagi seluruh proses manifestasi ke dalam karakter. Karakter tersebut yang akan membentuk berbagai perilaku massyarakat yang pada akhirnya termanifestasi ke dalam wujud fisik baik bangunan atau pola ruang permukiman.

Di samping nilai kehidupan, norma yang ada pada ajaran Aluk Todolo dalam bentuk sangka' dan pamali secara psikologis telah membangun pengetahuan lokal masyarakat Sillanan. Norma yang terdapat dalam ajaran Alukta, tampaknya masih melekat pada alam bawah sadar masyarakat Sillanan. Meskipun sudah berkeyakinan Kristen tetapi tampaknya kepercayaan terhadap adanya pamali masih melekat erat pada perilaku kehidupan masyarakat. Sebagai contohnya adalah masyarakat Sillanan masih menggunakan kosmologi sebagai dasar dalam membangun tongkonan sebagai objek utama permukiman. Pengetahuan terebut secara sistematis diturunkan oleh nenek moyang dengan memberikan aturan bermukim.

Konsepsi masyarakat Kristen Toraja yang berusaha untuk memisahkan antara adat dan agama tampaknya belum mampu merubah perilaku secara psikologis masyarakat Sillanan. Proses pemisahan ini tampaknya bertujuan untuk melakukan asimilasi kebudayaan Sillanan dengan teologi Kristen karena secara aturan agama beberapa ritual upacara terutama dalam upacara rambu tuka menyimpang dari syariat 
kepercayaan Kristen. Salah satu fenomena yang muncul dari usaha mengasimilasi kebudayaan adalah penyebutan Puang Matua yang diganti dengan Puang Yesus.

\section{Metafisika Tongkonan}

Hasil pelapisan ruang baik secara horizontal maupun vertikal. Pada ruang horizontal terdapat empat lapisan ruang yaitu : ruang sakral di sekitar Tongkonan Doa', ruang pada permukiman adat atau tradisional, ruang permukiman lama, dan ruang permukiman baru. Ruang sakral merupakan ruang komunal adat yang digunakan untuk melakukan ritual yang bersama dan untuk kepentingan bersama. Ruang permukiman tradisional merupakan kumpulan tongkonan yang merupakan simbol kolektifitas komunitas dalam bentuk konsensus dalam menjalankan kepemerintahan adat. Manifestasi konsensus diwujudkan dalam pembagian peran atau fungsi tongkonan baik tongkonan karua maupun tongkonan tumpu. Ruang permukiman lama merupakan ruang penyangga permukiman tradisional dimana perangkat pendukung tongkonan berada. Eksistensi perangkat seperti rante, bubun, ataupun lahan perkembunan merupakan wujud dukungan dari penyangga. Tongkonan bantu atau tumpu juga sebagian besar terletak pada permukiman lama. Sedangkan permukiman baru merupakan pengembangan permukiman paska kemerdekaan, dimana akses jalan sudah mulai dibuka sehingga masyarakat mempunyai pilihan tinggal di sekitar pengembangan jaringan jalan.

Pada lapisan ruang vertikal tampak adanya sebuah kesatuan dari realitas ruang. Setiap lapisan dibawahnya merupakan hasil penyingkapan dari keberadaan lapisan di atasnya. Artinya, terdapat relas teks konteks antara lapisan atas dengan lapisan dibawahnya. Lapisan tersebut merupakan kategorisasi dari tema dan konsep pembentuk ruang tongkonan. Kategori spirit merupakan manifestasi atau penyingkapan dari sifat atau nama Sang Pencipta. Penyingkapan ini bersifat individual (madoang atau cinta kepada leluhur) maupun komunal (toma'rapu atau persekutuan). Kategori aluk merupakan ruang religi yang menjadi sumber pengetahuan bagi masyarakat Sillanan. Pada saat ini terjadi transformasi dari pengetahuan Aluk Tojolo (sangka sola pamali) menjadi pengetahuan kristenism. Proses yang muncul tampaknya berupa inkulturasi kebudayaan antara budaya lokal dengan pengetahuan atau aturan agama Kristen.

Kategori adat merupakan wujud aktivitas masyarakat baik dalam bidang budaya, ekonomi, sosial, politik, dan kelembagaan. Dorongan kekuatan politik keagamaan dan perkembangan ekonomi karena perbaikan infrastruktur dan kondisi sosial politik merubah tatanan adat yang berbasis pada tradisi aluk. Beberapa aktivitas upacara terutama rambu tuka yang dianggap bertentangan dengan ajaran agama Kristen dilarang untuk dilakukan seperti sesaji kepada dewa atau pemberkatan tongkonan yang menggunakan tradisi alukta.

Tondok merupakan penyingkapan paling utama pada ruang fisik dimana tongkonan merupakan komponen utama yang ada pada sebuah tondok. Penyingkapan pada ruang fisik diwujudkan dalam berbagai tanda seperti keberadaan tongkonan 
berikut dengan perangkat pendukungnya, pergeseran pemanfaatan lahan karena dorongan ekonomi dan perkembangan infrastruktur maupun tanda-tanda lain yang ada pada maujud fisik.

Spiritualitas ruang tongkonan pada intinya adalah penyingkapan sifat ketuhanan ataupun keilahiahan ke dalam bentuk lapisan atau ruang kesadaran. Setiap lapisan ruang merupakan hasil manisfestasi ataupun penyingkapan dari nama atau sifat - sifat ketuhanan dari sifat yang masih berbentuk ide, pengetahuan, aktivitas sampai pada entitas yang berwujud fisik. Perencana berperan membantu membukakan penyingkapan realitas apa adanya dari Sang Pencipta. Keberagaman dalam setiap lapisan kesadaran merupakan bukti keimanan dari perencana akan keberadaan Sang Pencipta.

\section{Daftar Pus taka}

Bessant, A. (1999). A Study in Conciousness. Theosophical Publishing. Adyar.

Bigalke, T. W. (2005). Tana Toraja : A Social History of an Indonesian People. KILTV Press. Leiden.

Friedman, J. (1987). Planning in the Public Domain from Knowledge to Action. Priceton University Press. New Jersey.

Kobong, T. (2008). Injil dan Tongkonan (Inkarnasi, Kontekstualisasi dan Transformasi). BPK Gunung Mulia. Jakarta.

Krishnamurti, J. (1980) (terj). Satu-satunya Revolusi. Komunitas Krishnamurti. Jakarta.

Krishnamurti, J. (1982) (terj). Mendesaknya Kebutuhan Perubahan. Komunitas Krishnamurti. Jakarta.

Krishnamurti, J. (2008) (terj). Bebas dari yang Dikenal. Komunitas Krishnamurti. Jakarta.

Krishnamurti, J. (2009) (terj). Jaringan Kerja Pikiran. Komunitas Krishnamurti. Jakarta.

Lullulangi, M. dan Sampebua, O. (2007). Arsitektur Tradisional Toraja. Badan Penerbit Universitas Negeri Makassar, Makassar-Sulawesi Selatan.

Nooy-Palm, H. (1979). The Sa'dan-Toraja : Study of Their Social Life and Religion Vol I Organization, Symbols and Beliefs. KITLV. The Hague : Nijhoff.

Nooy-Palm, H. (1979). The Sa'dan-Toraja : Study of Their Social Life and Religion Vol II Rituals of The East and West. KITLV. The Hague : Nijhoff.

Perkins, J. S. (2004). A Geometry of Space and Conciousness. The Theosophical Publishing House. Adyar.

Sandarupa, S. (2012). Life and Death in Toraja. PT. Torindo (Toraja-Indonesia) MakassarSulawesi Selatan.

Wilber, K. (1985). The Spectrum of ConsciousnessThe Theosophical Publishing House. . Wheaton.

Wilber, K. (2000). Integral Psychology : Conciousness, Spirit, Phychology, Theraphy. Shambhala Publications. Massachusetts.

Wilber, K. (2001). A Theory of Everything : An Integral Vision for Business, Politics, Science, and Spirituality. Shambala. Boston.

Zukav, G. (1990). The Seat of The Soul. A Fireside Book. New York.

Waterson, R. (2009). Paths and Rivers Sa'dan Toraja Society in Transformation. NUS Press.

Singapore. 